\title{
A paradigmatic visionary perspective: professional master's in nursing
}

\author{
Uma perspectiva paradigmática visionária: mestrado profissional em enfermagem \\ Una perspectiva paradigmática visionaria: maestría profesional en enfermeira
}

Cláudio José de Souza', Zenith Rosa Silvino'
'Universidade Federal Fluminense. Niterói, Rio de Janeiro, Brazil.
How to cite this article:
Souza CJ, Silvino ZR. A paradigmatic visionary perspective: professional master's in nursing. Rev Bras Enferm [Internet].
2018;71(5):2584-8. DOI: http://dx.doi.org/10.1590/0034-7167-2018-0102

Submission: 03-05-2018

Approval: 05-17-2018

\section{ABSTRACT}

Objective: To reflect on the key concepts of the book The Structure of Scientific Revolutions and its applicability in professional master's in nursing. Method: This is a theoretical-reflective study that uses the philosophical and epistemological conceptions of the philosopher Thomas Samuel Kuhn to consider its applicability on the paradigm shift of stricto sensu graduate courses in nursing. The main concepts of Kuhn were used as support: paradigm, anomaly, scientific community and scientific revolution. Results: The propositions of this philosopher are applied to and support the theoretical reflection on professional master's programs, contributing to clarify what would be a paradigmatic visionary perspective in stricto sensu master's models in nursing. Conclusion: From Kuhn's propositions it was possible to conclude that professional master's programs in nursing can break away from the dominant paradigm, strengthening a scientific revolution within the academia.

Descriptors: Education, Nursing, Graduate; Education, Professional; Technological Development; Nursing; Health Postgraduate Programs.

\section{RESUMO}

Objetivo: Refletir sobre os conceitos-chave da obra A estrutura das revoluções científicas e sua aplicabilidade no mestrado profissional em enfermagem. Método: Estudo teórico-reflexivo, que parte das concepções filosóficas e epistemológicas do filósofo Thomas Samuel Kuhn a fim de pensar sua aplicabilidade na mudança de paradigma dos cursos de pós-graduação stricto sensu em enfermagem. Buscou-se suporte nos principais conceitos de Kuhn: paradigma, anomalia, comunidade científica e revolução científica. Resultados: As proposições do referido filósofo se aplicam e ao mesmo tempo sustentam a reflexão teórica sobre o mestrado profissional, contribuindo para aclarar o que seria uma perspectiva paradigmática visionária na modalidade stricto sensu de mestrado em enfermagem. Conclusão: Por meio das proposições de Kuhn foi possível concluir que os programas de mestrado profissional em enfermagem são capazes de romper com o paradigma dominante, potencializando uma revolução científica no âmbito acadêmico.

Descritores: Educação de Pós-Graduação em Enfermagem; Educação Profissionalizante; Desenvolvimento Tecnológico; Enfermagem; Programas de Pós-Graduação em Saúde.

\section{RESUMEN}

Objetivo: Reflexionar sobre los conceptos clave de la obra A estrutura das revoluções científicas y su aplicabilidad en el máster profesional en enfermería. Método: Estudio teórico-reflexivo que parte de las concepciones filosóficas y epistemológicas del filósofo Thomas Samuel Kuhn a fin de pensar su aplicabilidad en el cambio de paradigma de los cursos de postgrado stricto sensu en enfermería. Se buscó soporte en los principales conceptos de Kuhn: el paradigma, la anomalía, la comunidad científica y la revolución científica. Resultados: Las proposiciones del referido filósofo se aplican y al mismo tiempo sostienen la reflexión teórica sobre el máster profesional, contribuyendo a aclarar lo que sería una perspectiva paradigmática visionaria en la modalidad stricto sensu de maestría en enfermería. Conclusión: A través de las proposiciones de Kuhn se concluyó que los programas de maestría profesional en enfermería pueden romper con el paradigma dominante, potenciando una revolución científica en el ámbito académico.

Descriptores: Educación de Posgrado en Enfermería; Educación Profesional; Desarrollo Tecnológico; Enfermería; Programas de Posgradoem Salud. 


\section{INTRODUCTION}

Thomas Samuel Kuhn, theoretical physicist, is considered one of the most influential philosophers of science of the $20^{\text {th }}$ century, being recognized by the scientific community for his excellence in contemporary epistemology and for his contributions to the fields of philosophy and history of science, especially after the publication of his work The Structure of Scientific Revolutions in 1962. This book earned him recognition as one of the most influential contemporary scientists due to the various concepts outlined by him to describe the development of science, among which can be highlighted in this reflection: paradigm, anomaly, scientific community and scientific revolution.

From Kuhn's work it is possible to understand that the development of science occurs dynamically and cyclically. For the author, the paradigm is, among other definitions, a representation of a pattern to be followed. However, a single paradigm is not enough to elucidate all the anomalies (problems from the field of research). In this understanding, the members of the scientific community are responsible for presenting new proposals that, if accepted, could lead to a new paradigm and, consequently, to a scientific revolution in academia ${ }^{(1)}$.

When associating Kuhn's concepts with nursing teaching in stricto sensu graduate programs in Brazil we can observe that these concepts fit since the approval of the Bases and Guidelines Law (LDB) from 1961. Some topics in this law were liable to double understanding, in particular those in article no. 69. They needed further clarification from militants involved in the area after the approval, from both the academic and administrative points of view, requiring a conceptualization that was more precise and operational than doctrinaire ${ }^{(2)}$.

In 1965, Newton Sucupira was asked to weave some considerations about the LDB to clarify its dubious meanings, resulting in an opinion that structured the philosophical bases of Brazilian graduate programs. According to the document, known as Sucupira's Report (Parecer Sucupira), the development and rise of a country cannot be considered when its educational and research bases are fragile and have no consistent delineation. For his valuable contributions, Newton was recognized as the father of graduate programs in Brazil.

This report already envisioned different paths to implement graduate programs in Brazil: the academic and the professional, evidenced especially in the following excerpt: "its immediate goal is, without a doubt, to provide the student the deepening of knowledge that allows him to achieve a high standard of scientific or technical and professional competence, which is impossible to acquire in undergraduate programs alone $\mathrm{e}^{\prime \prime(3)}$.

Although the prospect of creating a professional master's was in the LDB, in Sucupira's Report and in other opinions written by experts in the area, the professionals assigned to constitute this teaching form in nursing, perhaps due to their professional praxis, preferred the creation of a strictly academic course that focused on the training of professors with master's degrees, ignoring the professional education model.

Both the scientific practice and stricto sensu models (professional master's) are understood to be based on paradigms, since the researchers and their advisees research their research objects from theoretical and conceptual bases, seeking to find applicable solutions to problems that emerge from professional praxis.

Thus, even when recognizing that theories of the philosopher Thomas Kuhn were not originally directed to the areas of health sciences and education, we realize that his concepts are applicable to the delineation of professional master's in nursing, since this teaching mode is based on the historical context in which Brazilian graduate programs, including nursing, were inserted over time ${ }^{(4)}$.

Given that nursing is immersed in the specifics and particularities of the daily process of building scientific and technical knowledge, the professional master's degree meets the need to break the old existing paradigm (academic master's) and the need to create a real scientific revolution in the academic field.

In this sense, by examining the work The Structure of Scientific Revolutions, we use Thomas Kuhn's propositions when he ratifies that "[...] universally recognized scientific accomplishments that for a time provide model problems and solutions to a community of practitioners"(1).

\section{OBJECTIVE}

To reflect on the key concepts of the book The Structure of Scientific Revolutions - paradigm, anomaly, scientific community and scientific revolution - and its applicability in professional master's in nursing.

\section{METHOD}

This is a theoretical reflection from an epistemological and philosophical perspective, about the key points of the work The Structure of Scientific Revolutions, by Thomas Samuel Kuhn ${ }^{(1)}$.

The article is organized into the following sections: "A tour of the key concepts of The Structure of Scientific Revolutions: the concept of paradigm"; "Processes of a scientific revolution"; and "A paradigmatic visionary perspective: professional master's in nursing".

\section{A TOUR OF THE KEY CONCEPTS OF THE STRUCTURE OF SCIENTIFIC REVOLUTIONS: THE CONCEPT OF PARADIGM}

The notion of paradigm is present in Linguistics since 1916, therefore, existing before Kuhn's book, published in 1962. However, it is from its use as a central concept in this work that the term was established in the philosophical and epistemological fields, spreading over several fields of knowledge, such as economics, sociology of work, bioethics, public health, health administration and biomedicine $\mathrm{e}^{(5)}$.

Although there are about of 21 definitions for the term "paradigm" in said work, Kuhn never claims that any definition would be more appropriate. In this article, we chose to emphasize the concept that corresponds to the transition from the academic to professional master's degree, i.e., a world model that comprises the set of theories that seek to explain the studied phenomena. Therefore, we can argue that a paradigm is a set of unconscious and assumed cognitive principles that allow us to interpret the world ${ }^{(1)}$.

For the philosopher, science as a set does not progress in the sense that successive theories converge for the truth and approach reality, but in the sense that the scientific revolutions represent transitions to better paradigms that produce more 
accurate solutions to increasingly numerous problems - in this particular case, the problems from professional practice. The truth takes as efficient and profitable what resists time and flourishes, as well as the real possibilities of a theory are linked to its chances of success. Thus, the ineffectiveness of the academia in responding to problems of professional practice shows the gap between academic research and its resolution in practice - furthermore, it demonstrates that nursing care needs different analyses that allow different interpretations.

Based on this assertion is that if we can link Kuhn's propositions with the transition of stricto sensu courses in Brazilian nursing. Because from these propositions we can observe, considering several ideas and contexts, the paradigms that were previously consolidated by the scientific community (in this case, the academic master's) and point the gaps in knowledge that act as springs for the creation of new paradigms (the professional master's). According to Kuhn, these multiple observations of an anomaly (puzzle/enigma) bring us even more close to a truth, even if temporary, thus, highlighting a possible "scientific revolution" that brings advances in science and reiterates or refutes the past paradigms ${ }^{(1)}$.

\section{PROCESSES OF A SCIENTIFIC REVOLUTION}

According to Kuhn, there are four crucial stages for a scientific revolution to occur ${ }^{(6)}$. For the first stage to occur, called "normal science", an established, consolidated and previous paradigm must exist - in the case of this reflection, the academic master's. The normal scientific research articulates phenomena and theories provided by the paradigm. This stage is depicted by the author as a theoretical-experimental puzzle, where the investigation is based on anomalies that a scientific community recognizes during a certain period of time as the basis for its practice. This stage has a critical significance, as it is on it that a new paradigm may or may not be born.

The second stage is called "anomaly". This moments presents the situations that are beyond the control of the crisis, i.e., the problems - and, why not say, the research objects? Currently, the idea that several academic productions are restricted to a select group with no applicability to problems arising from professional praxis no longer exists.

In the third stage, called "paradigm", a network of commitments and compliances can be conceived. The paradigm is what coordinates and directs the activities of a particular group who work on them - in this case, the scientific community. For some more revolutionary researchers, the academia must construct a dialogue with the general population, and not only with a distinct group. For them, the current paradigm (academic master's) is no longer sufficient to meet the demands from professional practice, and the movement, for two decades, of implementation of the professional master's did not envisioned the replacement of one for the other, but their integration.

The fourth stage is called "revolution/movement". The way what is real is observed changes; the previous paradigm is abandoned and another is adopted, conceived and defended by a scientific community. For Kuhn, this moment is cyclic and dynamic, since science itself needs to follow the transformations of its period. We must mention that this cycle may remain for a given period of time, until another anomaly is designed, thus generating a possible revolution in academia.

There is no doubt that, for Kuhn, science as a set does not progress in the sense that successive theories converge for the truth and approach reality, but in the sense that the scientific revolutions are transitions to better paradigms that produce more accurate solutions to increasingly numerous problems, especially of empirical nature. The central point of Kuhn's conception is the theory that the typical development of a scientific discipline occurs over a process that requires five stages ${ }^{(1)}$.

In the first stage, the pre-paradigm, the field of ideas is exhausted while seeking to answer the following questions about the paradigm being introduced: what phenomena must be studied by the new paradigm? How these phenomena should be studied? On what philosophical basis is the paradigm based? What are the theoretical principles on which the paradigm is based? How the philosophical and epistemological principles interrelate?

The pre-paradigm stage is marked by a turbulence of thoughts and a divergence among the own members of the scientific community, which no longer accepts the previous paradigm as the absolute "truth". Considering this proposition in our reflection, we comprehend that the academic master's was hegemonic in the field of nursing for almost four decades.

However, by realizing that a single academic paradigm was not enough to try to answer all questions, particularly those from professional practice, is that a group of researchers/scientists invested in the professional master's in nursing model, enabling other forms of making and designing research in academia.

When faced by this new dynamism, there was the need to redirect the real contributions that graduate school could offer to science and the world of labor. The professional master's model was designed considering these questions to add value not only to the academia, but also to professionals and users who rely on quality service. This integration between the academia and praxis allowed these professionals, who were away from the academia, to transform the problems from their professional practice in research objects and, through the epistemological and philosophical reflection, find or make the possibilities of resolution be feasible through their research, proposing some kind of technological production at the end.

How is a paradigm created? In an attempt to clarify this concept we will use a popular story from an unknown author, which represents exactly the concept of paradigm for normal science:

A group of scientists placed five monkeys in a cage and in the middle, a ladder with bananas on top. Every time a monkey climbed the ladder to get the bananas, the scientists soaked the rest of the monkeys with cold water. After a while, when a monkey tried to climb the ladder the others beat up the one on the ladder. After some time, no monkey tried to climb the ladder regardless of the temptation of the bananas. Then, the scientists replaced one of the five monkeys. The first thing the new monkey did was to climb the ladder, the monkey was quickly removed from it by the others who beat him up. After a few beatings, the new member of the group no longer climbed the ladder. A second monkey was replaced and the same occurred, the first replacement participated enthusiastically in beating the new member. A third monkey was replaced and the fact was repeated. Finally, the fourth and the last of the veterans were replaced. Then, the scientists had a group of 
five monkeys that, even though never received the cold shower, continued to beat up any monkey that tried to get the bananas. If it was possible to the monkeys why they beat those who tried to climb the ladder, surely their answer would be: I don't know, things have always been like that over here ${ }^{(7)}$.

In the second stage of the sequence, called "normal science", the thoughts are already previously clarified by members of the scientific community, to which the paradigm to be asserted is shown. At this point, a certain community of researchers realize that it is no longer possible to perform research that are limited to the libraries of universities and shown to a very restricted number of listeners. Usually, there is a turbulence within the group at this stage, since those who are more orthodox hesitate to not give in to the convictions of the new paradigm. However, another parcel, believing that to dare is an opportunity to break away from the current paradigm, reaffirms its proposals and originates another group that opposes the previous paradigm. Regarding the reflection presented, the professional master's mode is an exit for these creators and, at the same time, a possibility of answering the current problems of the praxis in all spheres where the professional nurse performs.

The third stage, crisis/revolution, is when the possibility of integration between research and the world of labor can be seen. In this case, a mode of training is assumed (professional master's), it meets the current needs from both the field of research and the world of labor. However, everything that is new causes insecurity, fear and discomfort. Given that it is a recent mode in the field of nursing, some more traditional researchers avoid it. Since in the early days of professional master's there were no criteria that differentiated it from the academic master's, generating a feeling of unfeasibility of the proposal.

In the fourth stage, the "new science", the assumptions of the new paradigm are accepted by the scientific community and by common sense. In the case of academic master's, this occurred through its recognition by Decree no. 080 of December 16, 1998 ${ }^{(8)}$ and its regulation through Decree no. 17 of December 28, $2009^{(9)}$. Despite being a model for only two decades, a movement, not only in nursing but in other areas of knowledge and production, can be perceived so the professional master's can be, in fact, a major paradigm shift in the late 20th century, capable of setting its own assumptions without the influence of the academic master's model.

The fifth stage, called "new crisis/revolution", is dynamic and not static. Maybe in the near future another kind of academic model can appear and start a new crisis and a new scientific revolution. In this conceptual framework, Kuhn points that, throughout history, the movement will be continuous and dynamic. These continuous concerns in the academic world are what make emerge, from time to time, a new paradigm.

\section{A PARADIGMATIC VISIONARY PERSPECTIVE: PROFES- SIONAL MASTER'S IN NURSING}

The construction of a product that is new, adapted or modified, emerges for the nursing care endowed with great complexity for its existence, given that the professional profile requested by the labor market is built dynamically in function of the transformations underwent by the contemporary world. In this perspective, the multidisciplinary character of health services and the changes of scientific knowledge make new and varied demands from society emerge for the educational system, and the system must construct a curriculum that meets the demands from the nursing labor market.

We believe that the experience and the doing - the praxis constantly challenge the ability and imagination of researchers; and this challenge is the spring that propels the solution of the enigma - the anomaly. We must note that the creators of the professional master's never claimed it as an independent model, since all research objects need philosophical and epistemological context. Thus, the professional master's degree does not intend separation, but the addition of new knowledge. Therefore, we highlight that studying problems that come from professional practice alone is not possible; The research must start from these studies and find possible solutions that are translated into various types of technological production - and nursing excels when doing this.

Between these discussions, the professional master's in nursing was created to favor the production of knowledge of professionals with extensive experience in various areas of knowledge, from the needs of everyday life and grounded on a philosophical contextualization, not simply on the empirical context.

When this movement for change is occurring, i.e., the abandonment of the previous paradigm and the conception of the current paradigm, there is a chance of science advancing through new or even old paradigms. Usually, at this point several random and conflicting theories and research can proliferate, since the previous paradigm (academic master's) is still established. However, once we evolve in this field of knowledge (professional master's), we can observe that the design become clearer, thus gaining more followers that start to understand this teaching modality as a possibility of integration of the policies of the Brazilian Unified Health System ${ }^{(2)}$.

Considering these ideas within the context of the professional master's in nursing and its relationship with its research objects, we assume that this process is in line with Thomas Kuhn's key concepts (paradigm, anomaly, scientific community and scientific revolution), since this training mode can strengthen not only nursing as a science, but Brazilian graduate programs.

We can consider that, in nursing, an anomaly is everything that somehow bothers or impairs the labor process, since nursing's goal is to make the processes be viable in any instance: organizational, professional or care procedures. On this understanding, the nurse who works in any of these areas does not consider the anomaly a threat, but the result of the complexity of a phenomenon that can and must be investigated. From this movement is that a new paradigm emerges: a certain group dissatisfied with the current paradigm, creates opportunities for reflection and discussion with members of the scientific community ${ }^{(10)}$.

Given these singularities, professional master's courses in nursing must conduct evidence-based research (thesis) that produce technological results that seek, for example, the rationalization of public and private spending and the integration and review of clinical and care protocols and of health technology. Always seeking to clarify its risks and benefits to the health of users, its cost-effectiveness and its impact to the organization of services and to the health of the population.

There are many possible products to be built at the end of the professional master's thesis, but it is important that these technological 
products, regardless of the setting in which they are performed (organizational, assistance or educational), are guided by the Brazilian priorities of research in nursing, considering the particularities of each service and its users. In a similar vein, the National Agenda of Priorities in Health Research is an excellent guide that, in addition to indicating the areas that need most attention from researchers, it strengthens nursing as a science and professional master's programs.

We expect that, in a visionary perspective, the professional master's in nursing is capable of strengthening its own paradigm, since it has been developed by nurses who share the same professional philosophy; for now, despite its significant advances, the model is still an emerging paradigm.

\section{CONCLUSION}

Before concluding our reflective expedition about the key concepts of the work The Structure of Scientific Revolutions, we shall resume the main aspects discussed.
First, we discussed the key concepts of said work, emphasizing the terms "paradigm" and "anomaly". In the topic "Processes of a scientific revolution", we discussed the normal science, the stages of change of paradigm and the focal point of Kuhn's conception, according to which the process that is being established for the construction of a theory must be based on a scientific discipline. In the third topic, "A paradigmatic visionary perspective: professional master's in nursing", we showed that the professional master's, by requiring an applied research, breaks with the previous paradigm, which is anchored on contemporary needs of conceiving and doing scientific research.

Therefore, we were capable of analyzing the professional master's model based on the propositions of the philosopher Thomas Samuel Kuhn, since his theory leads us to a study of the world's daily life and, especially, of science as a dynamic and cyclical product. Thus, we believe that his conjectures are applicable to the context of the paradigm shift from academic master's degrees to professional master's degrees.

\section{REFERENCES}

1. Kuhn TS. A estrutura das revoluções científicas. São Paulo: Perspectiva; 2011.

2. Sucupira N. Antecedentes e primórdios da pós-graduação. Forum Educ. 1980;4(4):3-18.

3. Almeida Jr A, Sucupira N, Salgado C, Barreto Filho J, Rocha e Silva M, Trigueiro D, et al. Parecer CFE n 977/65, aprovado em 3 dez. 1965: definição dos cursos de pós-graduação. Rev Bras Educ[Internet]. 2005[cited 2018 Feb 28];(30)162-73. Available from: http://www.scielo.br/pdf/rbedu/n30/a14n30.pdf

4. Pinhão AO. A transição de paradigma na ciência e na educação: uma possível contribuição de Thomas Kuhn para a formação inicial de professores. Rev Educ Perspec[Internet]. 2017[cited 2018 Feb 28];8(1):106-21. Available from: https://educacaoemperspectiva. ufv.br/index.php/ppgeufv/article/view/682/197

5. Jacobina RR. The paradigm of historical epistemology: Thomas Kuhn's contribution. Hist Cienc Saude-Manguinhos[Internet]. 2000[cited 2018 Feb 28];6(3):609-30. Available from: http://dx.doi.org/10.1590/S0104-59702000000400006

6. Kuhn TS. O caminho desde A Estrutura: ensaios filosóficos, com uma entrevista autobiográfica. São Paulo: Ed Unesp; 2006.

7. Freire OS, Soares A. Resumo comentado: a estrutura das revoluções científicas Thomas Kuhn[Internet]. Florianópolis: Instituto de Gestão de Mudanças Estratégicas Pessoais; 2010[cited 2018 Jul 19]. Available from: http://www.igmep.com.br/artigos/2010/5/18/ resumo-comentado-a-estrutura-das-revolucoes-cientificas-thomas-kuhn

8. Brasil. Ministério da Educação. Portaria n 080 de 16 de Dezembro de 1998: dispõe sobre o reconhecimento dos mestrados profissionais e dá outras providências, 16 de dezembro de 1998[cited 2018 Jul 19]. Available from: https://www.capes.gov.br/ images/stories/download/legislacao/Portaria_CAPES_080_1998.pdf

9. Brasil. Ministério da Educação. Portaria normativa $n^{\circ}$ 17, de 28 de dezembro de 2009: dispõe sobre o mestrado profissional no âmbito da Fundação Coordenação de Aperfeiçoamento de pessoal de Nível Superior - CAPES. Diário Oficial da União[Internet]. 29 de dezembro de 2009[cited 2018 Jan 11];6(3):609-30. Available from: http://www.capes.gov.br/images/stories/download/ legislacao/PortariaNormativa 17MP.pdf

10. Kuhn TS. A tensão essencial: estudos selecionados sobre tradição e mudança científica. São Paulo: Editora Unesp; 2011. 